Gerión. Revista de Historia Antigua

ISSN: 0213-0181

http://dx.doi.org/10.5209/geri.68588

\title{
The Spinning of the Wheels: Women's Travel Stories in Latin Funerary Inscriptions
}

\author{
Lien Foubert ${ }^{1}$
}

Recibido: 9 de mayo de 2019 / Aceptado:

\begin{abstract}
This contribution examines Latin funerary inscriptions in which the movements of middleclass women within and beyond the Italian peninsula constitute the focus point of the text. It aims to shed light on how these texts relate to other social discourses, such as those centred on class and gender. Travel is by default a disruptive activity as it took women out of the household and into the public world. When a commemorator made the deliberate choice to include a reference to a woman's journey, he or she must have been well aware of the fact that such an inclusion deviated from the canonical description of a woman as an ideal matrona. In this article, I will argue that this awareness and the desire to conform to the dominant ideological discourses of their time led to the embedment of these small travel accounts in a broader discourse of ideal female conduct.
\end{abstract}

Keywords: Matrona; Violent Death; Mobility; Middle-Class Women; Narrative Strategies.

\section{[es] Ruedas que giran: historias de viajes femeninos en inscripciones funerarias latinas}

Resumen. Este artículo analiza un conjunto de inscripciones funerarias latinas que tratan de la movilidad geográfica de mujeres de clase media dentro y fuera de la península italiana. Propone poner de manifiesto la relación que tienen estos textos con otros discursos sociales, como los centrados en cuestiones de clase y género. Viajar es una actividad disruptiva que permitía a la mujer salir del hogar e introducirse en la esfera pública. Cuando un dedicante tomaba conscientemente la decisión de mencionar el viaje de una mujer, él o ella estaría seguramente al tanto de que tal mención se desviaba de la descripción canónica de la mujer ideal, la matrona. Se argumentará que el deseo de adecuarse a los discursos ideológicos dominantes de la época fue el motivo de que estos cortos relatos de viaje sean integrados en una discusión más amplia sobre el comportamiento femenino ideal.

Palabras clave: matrona; muerte violenta; movilidad; mujeres de media clase; estrategias narrativas.

Sumario: 1. Introduction. 2. One amongst many or individuals after all? 3. Female mobility in Latin inscriptions. 4. Shipwrecks and hardship en route. 5. A peregrinatio out of devotion. 6. Conclusion. 7. References.

Cómo citar: Foubert, L. (2020): The Spinning of the Wheels: Women's Travel Stories in Latin Funerary Inscriptions, en Gerión 38/1, 137-156. 


\section{Introduction}

In Roman antiquity, mobility was to a large extent limited by external factors: public transportation did not exist, not everyone had access to a road or water system that could take you safely from one place to another, many could probably not spare the time to take a trip as their livelihood depended on continuous labour, the lack of financial means limited the travel possibilities, etcetera. Modern scholars assume that gender roles also limited travel. Because of this, even though classical scholars have underscored the centrality of mobility in the Roman Empire, research on the movements of women -as a separate societal group- is limited. ${ }^{2}$ In general, 'movers' are often perceived of as faceless and sex-less crowds. The only exceptions taken into account are those women whose travel activities are documented by the ancient writers. Needless to say, these women belonged to the upper classes of Roman society. From the literary sources it appears that elite women did indeed travel, usually while accompanying male relatives whose public duties dictated the itinerary, activities and circumstances en route. Over time these journeys became common practice. Yet, they remained subject of debate. The most often voiced criticism was that the new environment and the (perceived) lack of social control abroad easily corrupted women travellers: they ignored social rules of conduct; they forgot to behave like a Roman matrona, a socio-cultural construct with a strict set of rules, which was dominant throughout Roman antiquity, as will be discussed below. ${ }^{3}$

Yet, previous research has shown that not only elite women travelled. An examination of mobility patterns in papyri, ostraca and graffiti in Roman Egypt has shown that women from the lower classes were mobile as well. Female relatives of soldiers occur most often in the source material, but women who travelled because of professional, religious or juridical reasons are also attested. Obviously, due to the nature of the sources, the conclusions drawn are one-sided as the Egyptian landscape dictated a particular type of travel that is not necessarily comparable to elsewhere in the Roman Empire. Contrary to the literary sources discussing the travel conduct of upper-class women, the travel accounts of the lower classes are very practical in content (i.e. discussing means of transportation, goods they carried, the state of the Nile or the roads, incidents along the way, etc.) and they do not appropriate ideological commonplaces as to how to behave en route. ${ }^{4}$

Rome's elite women travellers attested in the literary sources and Egypt's mobile women in the papyrological sources constitute almost two extremes of the social (and geographical) spectrum of the mobile society in the Roman Empire. Taking the state of current scholarship into account, the question that remains is whether there is a way to trace the travel activities and the discourses involved of those in between, i.e. the so-called middle-classes or 'ordinary' women in the remainder of the Roman Empire. A source type that has rarely been examined in this regard are the epigraphic sources. This should not surprise us. Although women have left traces of their journeys in funerary or votive inscriptions, the vocabulary used to describe

See, for instance, Horden - Purcell 2000; Moatti - Kaiser 2007; Guédon 2010; Iglesias Gil - Ruiz Gutiérrez 2011; Tacoma 2016; Isayev 2017.

On these social debates, see most recently Foubert 2016a, 462-487. See also Mirón 2008, 233-254; Parker 2008, 229-243.

4 Foubert 2016b, 285-304. See also Frass 2006, 485-497. 
their journeys is by no means standardized. Moreover, the fact that we are dealing with a woman traveller often only becomes clear after a careful examination of the historical context (e.g. nomenclature, find spot of the inscription, references to a husband's offices). The scholar looking for them, therefore, sees him or herself faced with a time consuming task, as I will explain in more detail below. So far, these sources have often remained hidden in bulky epigraphic corpora.

This contribution aims to fill part of that gap. An analysis of a sample of Latin funerary inscriptions in which women's travel activities are central to the narrative will illustrate how epitaphs offer insight in the ideological discourses involved. ${ }^{5}$ Questions that will be addressed are: How do the writers of these texts frame the journeys of women? What do they find important to emphasize? In what way do the narratives differ from or coincide with the dominant ideological discourses of their time? This is by no means an exhaustive analysis. It serves first and foremost to illustrate why it is worthwhile to pay attention to these sources in order to gain a better understanding of the social mechanisms of the Roman Empire and its society at large.

\section{One amongst many or individuals after all?}

This contribution is about narrative strategies. In no way does it try to gain insight in women's lived reality, for as Werner Riess explains with regard to Roman funerary inscriptions: "Because epigraphic formulae are highly stereotypical and standardized over centuries, Latin epigraphy offers no access to the real women hidden behind its highly formulaic texts". ${ }^{6}$ A similar observation could be made for Greek epigraphy, where, though inscriptions during the Hellenistic and Roman period pay more attention to the individual than during the Classical period, women tend to be characterised by means of the same values throughout the centuries. ${ }^{7}$ Both Latin and Greek inscriptions appropriate ideological commonplaces to construct an image of the woman figuring in the epitaph as an embodiment of ideal behaviour, whether she is the deceased or the commemorator. In Latin, the values often referred to are pudicitia (sexual virtue), castitas (chastity), pietas (piety), modestia or verecundia (modesty), to have a pleasant way of conversing, and to be of sound mind; in Greek, recurring characteristics are being chreste (excellent), sophron (self-controlled), agathe (good), and eusebes (pious). In addition to these, women were also more often than not commemorated for their role in the household and family: they were identified and praised as mothers, wives, daughters and sisters. ${ }^{8}$ It did not make a difference whether the epitaph was commissioned by a man or a woman: both used the same formulae and conventions. In the Roman period, the socio-cultural construct of the matrona embodied this entire set of canonical

\footnotetext{
For pragmatic reasons, this contribution will only focus on Latin funerary inscriptions. It goes without saying that a study of Greek funerary inscriptions, as well as Latin and Greek votive and honorary inscriptions would provide a more complete picture.

Riess 2012, 491.

Wypustek 2013, 3.

Women were also remembered and praised as benefactresses and priestesses. On this, see above all Van Bremen 1996; Hemelrijk 2017; Navarro Caballero 2017.
} 
female values. ${ }^{9}$ Matrona received a normative dimension: it served to describe expected behaviour and, at the same time, functioned as a means of evaluating women's actual conduct.

Gender historians call characteristics of womanhood such as these 'dominant': they are widely endorsed, appearing for instance in ancient literature, juridical texts, imagery, and -the focus point of this contribution- funerary inscriptions, and they contribute to the existing hierarchical society in which men are considered superior to women. ${ }^{10}$ This particular set of feminine attributes, classified under the label of matrona, seemed natural to Roman society in the sense that this is what Roman women naturally were. The same discourse appeared in Greek society, though a term parallel to the Latin matrona was absent. Women were considered weak, unstable and emotional and, therefore, nature had decided that they were not suited to operate in the public sphere. Graeco-Roman society assigned them to the private world of the household, which was considered their natural domain. Like every other ideology, the ancient ideal of womanhood was a dynamic socio-cultural construction and its dominant character and relevance to society needed to be negotiated time and time again, of which the funerary inscriptions referring to women's travels that are examined in this article are an illustration.

If one template was dominant and sufficient to describe thousands of women throughout the ages and across different social strata and geographic regions, how then, as Werner Riess has aptly phrased, did men and women "emphasize that their female relatives were not merely generic types but individuals, human beings of flesh and blood"? ${ }^{11}$ Riess discerns two main strategies. Firstly, a commemorator could enumerate the deceased woman's qualities at length, sometimes adding that she surpassed all women of her age and before. A second strategy, was to include unusual formulations, metaphors or imagery. However, it appears that if one decided to deviate from the canonical set of virtues one walked a thin line: often, such inclusions were counterbalanced by also alluding to the woman's appropriation of traditional values, thus combining both strategies in one inscription. Riess mentions references to a woman's sex appeal or, as in the case of the well-known Laudatio Turiae, to a woman's political activities or public achievements as illustrations of such unusual formulations. With this contribution, I would like to add references to women's travel activities to this set of deviations.

\section{Female mobility in Latin inscriptions}

Before we turn to an in-depth analysis of a selection of funerary inscriptions, it would be worthwhile to elaborate on the make-up of references to mobile women in the epigraphic source material as a whole. One could argue that epigraphic attestations

\footnotetext{
On the idea of the matrona, see, for instance Fischler 1994, 115-133; Cantarella 2001; Cenerini, 2009. Most recently see Pavón 2018.

10 One could also speak of "emphasized femininity" (coined in Connell 1987, 183-188), because matrona is "a form of femininity that is practiced in a complimentary, compliant and accommodating subordinate relationship with hegemonic masculinity", i.e. the idealized Roman elite man. For the quote, see Messerschmidt 2011, 206207.

11 Riess 2012, 493.
} 
of female mobility are as diverse as there are types of mobility. People travelled short, medium or long distances; journeys had a seasonal, temporary or permanent character, or they may start as one and end up as another. Movement could have been voluntarily or forced. The ancient sources are rarely explicit about the character of a journey, making it almost impossible for modern scholars to categorise it in any of these conventional typologies. It should not surprise us, therefore, that studies on human movement in Antiquity, for pragmatic reasons, often refrain from providing a definition of 'mobility' or render a very broad one.

An exhaustive examination of the movements of women based on the epigraphic sources has not yet been done, but scholars have increasingly used gender as a differentiating criterium when conducting research on human movement more generally. As a result of the so-called 'mobility turn' in the social sciences during the 1990s, classical scholarship has seen a boom in research on human migration and what has been labelled 'foreigners' ${ }^{12}$ Two examples of this trend will suffice to illustrate the extent to which women were present among the 'movers'. In 2000, David Noy published Foreigners at Rome, in which he collected inscriptions, primarily dated to the imperial period, that attest to the presence of those who were "born outside Italy and moved to Rome, but continued to have a 'home' (in their own thinking or in other people's) elsewhere". He clarifies that

most foreigners were immigrants, but since some were at Rome for temporary reasons rather than with the intention of settling permanently, it is their status as 'foreign' rather than as 'immigrant' which determines their inclusion here, given the impracticability of separating temporary visitors from permanent migrants in most of the evidence. ${ }^{13}$

Of the 681 individuals in Noy's epigraphic corpus of which the gender could be determined 147 are female, slightly less than $22 \%$.

A second example is Mark Handley's 2011 monograph Dying on Foreign Shores, in which he collected "623 examples of travellers or foreigners - of whom 251 were Easterners- recorded on 567 inscriptions", in the late-antique West. ${ }^{14}$ Similar to what I argued above, and in the same spirit as Noy's definition, Handley states that "the number of possible ways to try to identify travellers and foreigners are many and varied. In the end, however, many such possibilities prove illusory." Instead of applying a definition as a guiding principle, he relied on specific criteria such as an explicit mention of a person's city or region of origin, the use of a regionally-specific calendar, but also professions or occupations of which common sense suggests that movement was involved. In his corpus, a gender could be assigned to 585 individuals; 92 of them were female, slightly less than $16 \%$. Though the majority of movers in the epigraphic source material are men, women proof to have been far from immobile in the Roman world both during the imperial period and in late Antiquity.

12 Since the state of modern scholarship with regard to human mobility in the ancient world is discussed in detail in several recent studies, which usually examine movement patterns while engaging with modern migration theory, I will not provide an overview of my own. See for instance, Tacoma 2016, esp. chapters 1 and 2; Isayev 2017, esp. chapters 1 and 2. See also the edited volumes De Ligt - Tacoma 2016; Lo Cascio - Tacoma 2016; Yoo - Zerbini - Barron 2019.

13 Noy 2000, xi.

14 Handley 2011, 13. 
Handley's criteria point to some of the ways in which women travellers were identified in inscriptions. A brief reference to a woman's place of origin already characterised her as a 'mover', such as in the Greek example of Flavia Charis who was buried in the provincia Arabia in the town Soada (also known as Dionysias) in the second or third century:

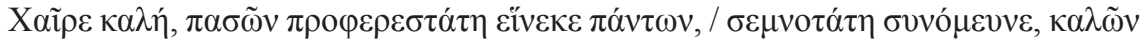

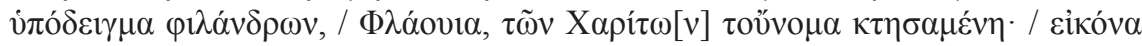

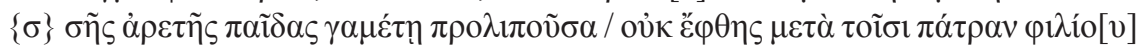

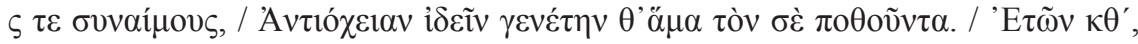
$\mu \eta \nu \tilde{\omega} \nu \mathrm{i}^{\prime}{ }^{15}$

Farewell beauty, most excellent of all women in all respects, / noblest spouse, model for all beauties who love their men, / Flavia, who got your name from the Charites; / having left your husband children as an image of your virtue, / you were not in time to see again with them your fatherland Antioch, / your beloved kinsmen and also your father who longs for you. / Twenty nine years and ten months old. ${ }^{16}$

Flavia Charis' beauty is emphasised as well as her exemplary role as a wife and mother, thus appropriating the traditional set of female values. In addition, the epitaph makes clear that she had moved from Antioch, having covered a distance of about $540 \mathrm{~km}$. A similar strategy is used in the case of Urbanilla, whose epitaph also dates to the second or third century and was found in Sommet el Amra in Africa Proconsulare:

Urbanilla mihi coniunx verecundia plena hic sita est / Romae comes negotiorum socia par $<c=s>$ imonio fulta / bene gestis omnibus cum in patria mecum rediret / au miseram Carthago mihi eripuit sociam / nulla spes vivendi mihi sine coniuge tali / illa domum servare meam illa et consilio iuvare / luce privata misera qu(i) escit in marmore clusa / Lucius ego coniunx hic te marmore texi / (h)anc nobis sorte dedit fatu(m) cum luci daremur // Urbanilla. ${ }^{17}$

Urbanilla, my wife, a woman of complete modesty, is buried here. / Rudder for my enterprises, supported by parsimony, my companion at Rome. / But when, having success in all my enterprises, I returned to my homeland with her. / Ah, Carthage, snatched away my pitiful companion from me. / No hope of livelihood remains for me without such a wife. / In my home she supported me, in my plans she assisted me. / Light-deprived, she pitifully finds her rest shut up in marble. / Lucius, your husband, here has covered you with marble. / Afore we were born, fate allotted this lot to us. // Urbanilla. ${ }^{18}$

\footnotetext{
15 SGO 22/36/01.

16 Unless stated otherwise, all translations are my own. Here, I follow the reading and translation of Tacoma Tybout 2019, 47.

17 CIL VIII 152 (=CLE $516=$ ILTun $0297=$ CLEAfrique 6).

18 The translation is taken from Parkin - Pomeroy 2007, 94.
} 
Urbanilla's epitaph, written in verse by her husband Lucius, starts by emphasising her verecundia, which replaced modestia in the later Roman empire as a popular term to express modesty. After that, Urbanilla is described in various manners as a partner to her husband, in business and otherwise, which in the end resulted in her journey from Rome to Carthage. To my knowledge, there is no other inscription in which a woman is so emphatically described as a participant in commercial activities. Yet, Lucius clearly frames it as a role she took upon her out of devotion to her husband, thus making her role as uxor the one to remember far and foremost. In the entire inscription, he leaves no doubt as to who is the active agent in their life choices: he took her to his homeland, covering a distance of about $1000 \mathrm{~km}$.

The examples of Flavia Charis and Urbanilla explicitly state that they were mobile at some point in their lives. The researcher examining female travel patterns could also be confronted with subtler narrative strategies, as the example of Vibia Pacata in northern Britain shows:

Silvanis [et] / Quadr(i)vi(i)s Ca[e]/lestib(us) sacr(um) / Vibia Pacata / Fl(avi)
Verecundi / (centurionis) leg(ionis) VI Vic(tricis) / cum suis / v(otum) s(olvit)
l(ibens) m(erito). ${ }^{19}$

Sacred to the heavenly goddesses of the woods and of the crossroads: Vibia Pacata, wife of Flavius Verecundus, centurion of the Sixth Legion Victrix, with her family willingly and deservedly fulfilled her vow. ${ }^{20}$

When taking the inscription at face value, one would not categorise Vibia Pacata among the movers. However, a closer look reveals that she probably had Pannonian roots: the combination of deities to whom this votive inscription is dedicated only occurs in Pannonia Superior, with Vibia Pacata's inscription as the only exception. Moreover, her husband Flavius Verecundus is known from another inscription which also puts him in Pannonia. As explained elsewhere, circumstantial evidence also points to a stay in North Africa for the both of them..$^{21}$ Though the inscription does not make the couple's mobile lifestyle explicit, a careful analysis of the inscription's narrative allows for a scenario in which Vibia Pacata and her husband covered a distance of at least $2000 \mathrm{~km}$.

Considering the time-consuming process to read between the lines of inscriptions such as Vibia Pacata's, the present article does not aim at giving an exhaustive examination of all funerary inscriptions of women travellers. Instead, I will analyse a sample of epitaphs in which the reference to a woman's travel activities does not figure as a side note or is hidden underneath the content at face-value, but in which her journey is central to her representation. ${ }^{22}$ For it is inscriptions such as these that allow

\footnotetext{
RIB 3, 3504 (=AE 1964, 175).

20 The translation is my own. Vibia Pacata's inscription is different from the other inscriptions dealt with in this article for it is a votive and not a funerary inscription. However, its different function does not impact on the conclusion drawn.

21 Foubert 2013, 391-403.

22 As explained, ideally, to put together a representative corpus, one would systematically go through the entire Corpus Inscriptionum Latinarum. As this would go beyond the scope of this article, for the underlying contribution I have instead selected inscriptions that are among the most often cited inscriptions in scholarly literature, the richness of the text and imagery constituting the most important criterion. The present article
} 
for an in-depth analysis of the various ideological discourses used by those who set up the funerary memorial. When available, I will also discuss the funerary monument as a whole, including its imagery. The order in which they will be examined is motivated by what makes each epitaph exceptional compared to the others: the funerary monuments of Iulia Secunda and her mother Cornelia Tyche and of Pontia stand out because of their sheer length and detailed decoration, those of Faenia Filumena and Aureliana because they are both rare examples of inscriptions in which a journey is commemorated by way of the Latin peregrinare, Martina's inscription is a rare ego-document of a woman characterising herself as a traveller, while the remaining epitaph of Maccusa Muceris and her sister Victoria/Valeriosa illustrates that women whose primary social role was not that of a married matrona could also deserve to have their journey commemorated.

\section{Shipwrecks and hardship en route}

The Roman epitaph of Cornelia Tyche and her daughter Iulia Secunda, set up by their husband and father Iulius Secundus, describes how both women drowned in the area of the north-eastern coast of Spain..$^{23}$ The cinerarium was found in 1498 in the Campus Martius and probably dates to the period 150-200 CE. It moved from one private collection to another and finally ended up in the Musée du Louvre. ${ }^{24}$ Throughout the ages the monument has been heavily damaged, with the removal of a large part of the inscription as a result. What remains of the monument is an inscription and carved imagery on the front panel, and a small part of the inscription on the left side panel. For an impression of the cinerarium in its original state we depend on different drawings, of varying artistic quality, from the sixteenth and eighteenth centuries. ${ }^{25}$ The front holds two female busts standing on acanthus leaves, set into a shallow niche, of which the woman on the left is pictured younger than the woman on the right. The portraits are flanked by two Corinthian columns that support a decorated pediment, carrying an inscription which identifies the women as -from left to right- "Iulia Secunda, daughter", and "Cornelia Tyche, wife". The columns rest on an inscribed base, divided in two halves. Each half contains an inscription that lists the age, virtues and qualities of its respective subject:

Front panel, left column: Et forma singulari et / moribus piissimis doctri/naq(ue) super legitimam / sexus sui aetatem prae/stantissimae quae vixit / annis XI mens(ibus) VIIII d(iebus) XX

Front panel, right column: Et incomparabilis erga / maritum adfectus sancti/ tatisque et eximiae erga / liberos pietatis quae / vixit annis XXXVIIII mens(ibus) / IIII d(iebus) VII ex is mecum ann(is) XI'

wants to illustrate that studying these epitaphs from an entirely new angle can offer us new insights in social processes in the Roman world. For ways to broaden the sample, see the conclusion below.

23 The scholarly literature on shipwrecks as a funerary motif is extensive. See, for instance, Fenet 2011, with further references.

24 See the $C I L$ edition for an overview.

25 The drawing of Petrus Appianus in 1534 is analysed and discussed in Williams 1940-1941, 47-66. The drawing made by Giovanni Antonio Dosio in circa 1559-1565 is published and discussed in Casamassima - Rubinstein 1993, no. 35 (with a list of other drawings on page 55). See also de Montfaucon 1722, 79, plate lvii.

26 CIL VI $20674(=C L E 436=A E 2013,152)$. 
Front panel, left column: Both by her exceptional beauty and by her most devout way of life she was outstanding by her learning beyond what was to be expected for her sex and age. She lived for eleven years, nine months and twenty days.

Front panel, right column: She was unmatched both in her affection to her husband and her devoutness, and showed great devotion to her children. She lived thirty nine years, four months and seven days, eleven and a half years with me. ${ }^{27}$

Both women are dressed in a mantle and tunic, which falls in less deep folds on Julia Secunda's breast than on Cornelia Tyche's, giving the impression of a lighter and perhaps more playful fabric, thus marking the age difference. Cornelia Tyche's hairstyle is of a type that was fashionable at the time of Faustina the Elder, with side waves and a coil on top, which suggests a date in the second century CE. Julia Secunda's hairstyle is less elaborate, simply drawn back from a central parting, which gives her a more youthful appearance. The decorations on the pediment are, lined up from left to right, a quiver, a bow, two empty chairs with the letters $D$ (is) M(anibus) set between the legs, a cornucopia, a torch, a rudder and a wheel.

Based on the sixteenth and eighteenth century drawings, the inscription on the side panel could be reconstructed as follows:

Iam datus est finis vitae iam / paussa malorum / vobis quas habet hoc gnatam / matremq(ue) sepulcrum / litore Phocaico pelagi vi / exanimatas / illic unde Tagus et nobile / flumen Hiberus / vorsum ortus vorsum occa/sus fluit alter et alter / stagna sub oceani Tagus et / Tyrrhenica Hiberus / sic etenim duxere ollim / primordia Parcae / et never $<$ unt $=$ E $>$ super vobis vitalia fila / cum primum Lucina daret / lucemq(ue) animamque / ut vitae diversa dies foret u/naque leti / nobis porro alia est trino / de nemine fati / dicta dies leti quam pro/pagare suopte / visum ollis tacito arbitrio / cum lege perenni / sisti quae cunctos iubet ad / vadimonia mortis // Iulius Secundus // D(is) M(anibus) / Iuliae Secundae filiae Corneliae Tyches uxoris / et forma singulari et / moribus piissimis doctri/naq(ue) super legitimam / sexus sui aetatem prae/stantissimae quae vixit / annis XI mens(ibus) VIIII d(iebus) XX / et incomparabilis erga / maritum adfectus sancti/tatisque et eximiae erga / liberos pietatis quae / vixit annis XXXVIIII mens(ibus) IIII d(iebus) VII ex is mecum ann(os) XI.

Now the end of life and relief from troubles has been granted to you, mother and daughter held in this tomb. You were deprived of life off the coast around Marseille by the violence of the sea, in the area from which the Tagus and the famous river Ebro flow respectively west and east, the Tagus to the waters of the Atlantic and the Ebro to those of the Mediterranean. For that is how the Fates long ago laid out their web and spun the threads of life over you, so that your birthday should be different but the day of your death identical. For me yet a different day of death has been appointed from the triple spinning of destiny. They resolved to postpone this according to their unuttered decision linked with the everlasting law which orders all to appear to answer the bail which they have given to death.

27 The translation of the inscription is taken from the Europeana Eagle Project. 
Bernard de Montfaucon explains in 1722 that the side panel also contained a carved image of an animal: "L'inscription est partagée en deux par la figure d'une bête à quatre pieds, qu'il n'est pas aisé de reconnoitre." Puzzled by this image, as well as by the symbols on the front panel, he adds: "Ce sont des mystères où je ne puis penetrer." ${ }^{28}$ Fortunately, part of these mysteries have been explained in more recent years.

Judging from the size of their funeral monument and the quality and quantity of its memorial carving, the women belonged to a wealthy family. Their precise status remains uncertain. The dedicator's name, Iulius Secundus, only becomes clear when putting the initial letter of the epigram's fourteen lines one after the other; his occupation or background is not mentioned. Altars like this were particularly popular amongst people from the middle stratum of society. ${ }^{29}$ Moreover, the mother's second name Tyche was often used for freedwomen. The fact that the monument was set up in Rome suggests that that was their family's home and the place where Iulius Secundus lived together with at least one other child, judging from the inscription, after their deaths. Why both women would have travelled as far as Spain remains unclear. Perhaps they had family there? It should not be excluded that Iulius Secundus was with them during the shipwreck or in the vicinity when it happened. The inscription states that the tomb 'held' both women, which could indicate that their remains were transported to Rome, a practice for which we have evidence elsewhere..$^{30}$ Iulius Secundus' familiarity with the region would be an explanation for its extensive description in the epigram, as if he wanted to show off not only his literary talent but also the extent of his geographical knowledge and perhaps even travel experience.

The cornucopia, torch, rudder and wheel are all attributes that are standardly associated with the goddess Fortuna or Tyche. They clearly constitute a pun on the name of the deceased, Cornelia Tyche. The quiver and the bow are standard attributes of the goddess Diana, which would make it likely that the animal on the side panel represents Diana's stag. It was common practice to associate young unmarried girls with the goddess. Research has shown that people from the middle classes in particular liked to emphasise the individuality of their deceased family members in funerary monuments. Associations with deities were part of this commemorative strategy. ${ }^{31}$ By appropriating this narrative commonplace, the dedicator of the monument contextualised him and his family within the values of Roman society. Yet, at the same time, as Janet Huskinson explains, it draws attention to the violent death of both women. The goddess Fortuna/Tyche was associated with good fortune and concord in marriage, an association that given Cornelia Tyche's characterisation as a devoted wife in the inscription would have been most welcome, but also evoked the idea of a cosmic force and inevitable destiny. ${ }^{32}$ An idea that is strengthened by the epigram's reference to the working of Fate, personified by the Parcae.

To sum up, Iulius Secundus' memorial to his wife and daughter emphasises their extraordinary death, both because it happened far away and because of its violent nature. At the same time, he anchors his memory practice firmly in different dominant

\footnotetext{
De Montfaucon 1722, 79.

Huskinson 2011, 115.

See Tybout 2016, 390-437.

See, above all, Wrede 1981.

Huskinson 2011, 119.
} 
discourses of his time: on the one hand, the women are characterised as exempla and, on the other, the monument is in line, both in image and text, with what was a popular way of remembering and of self-representation. These different narrative strategies stress the individuality of Cornelia Tyche and Iulia Secunda and makes them one amongst many other women at the same time.

Before we turn to a second elaborate funerary narrative, that of Pontia, it is worthwhile to have a look at a parallel, though less detailed in appearance, epitaph of Eufronia who also died during a shipwreck:

\section{Eufronia E[ufr(oni)] / filia et m[at(er)] / naufragio [e]/necta nat[a] / pri(die) Kal(endas) No[v(embres)] / percepit / III Id(us) April(es) / decessit / pri(die) Kal(endas) Mai(as) $)^{33}$}

Eufronia, daughter of Eufronius, and mother. She died in a shipwreck. She was born on 31 October, she gave birth on 11 April, and she perished on 30 April.

Her memorial was set up in Autun in Gaul, where she and her relatives presumably lived, and dates to the fourth century CE. The personal drama in this inscription not only stems from the cause of death, but also from the fact that Eufronia appears to have been a young mother, if one can assume that the accident happened in the same year as Eufronia's delivery, which might well have been the case considering the emphasis on both episodes in this short inscription. There is little information on the social status of Eufronia. The Corpus Inscriptionum Latinarum, however, mentions that the inscription was seen by an accompanying image of a female figure resembling a priestess: "une grande figure qui a la moitié du visage emportée, au pieds de laquelle il y a comme une sorte de fourneau duquelle sort une flamme (Mun.), une Vestale ou prêtresse (Thom.)". It remains possible, therefore, that Eufronia was a priestess.

The fourth century inscription, found in Carsulae in Umbria, commemorating Pontia is detailed in its account as well as its decoration. What is left to us is the front-facing long side of a sarcophagus, broken in two pieces, in which an inscription is engraved on two panels. The circular structure that separated the two in the middle is heavily damaged. It probably contained a figuration of Christ flanked by an alpha, still partly visible, and an omega; his left hand holds an open codex; it was also encircled by four symmetrically placed four-petaled flowers, of which two remain. At the far end corners of the two fragments there are sculpted figures, standing in profile. Left stands a female figure facing left towards a second person who is now missing from the panel. She turns her back to a curtain, as if she has just stepped out from behind it. The female figure is wearing a tunica and palla, her hair is decorated with a ribbon or diadem. On the other end, there seems to have been a parallel composition of which the left female figure remains, dressed in the same way, but without a curtain in the background. It has been assumed that the sculptural figures represent the deceased who interacts with the Muses. Underneath the sculpted figures there are traces of engraving which seem to have been added later and read as a legend to the images. The left has been reconstructed as [Hic audit Ura]niam, "Here she (?) listens to Urania". The engraving that accompanies the

CIL XIII 2718 ( $=I L C V 1540)$. 
composition on the right reads Hic legit autores $m u$ [- - -], which can be interpreted both as "Here she (?) listens to musical composers" as well as "Here she (?) listens to many authors". ${ }^{34}$ Even though the epitaph has been preserved in its entirety, its metric text is as puzzling as its accompanying sculptural decorations:

Left tablet: Pontia sidereis aspirans vultibus olim / hic iacet aetherio semine lapsa fuit / omn $<i=e>$ es honos omnis ces(s)it tibi gratia formae / mens quoque cum vultus digna nitore fuit / tradita virgo toris decimum non pertulit annum / coniugii infelix unica prole perit / quantus amor mentis probitas quam grata marito / quam casti mores quantus et ipse pudor / ni(hi)l tibi quod foedum vitium nec moribus ullum / dum satis obsequeris famula dicta viri

Right tablet: denique te, memet fatis odioque gravatum / dum sequeris vidit Corsica cum lacrimis, / tu Treviros pergens cursu subvecta rotarum, / coniugis heu cultrix, dura satis pateris. / te pater infestus genero cum tollere vellet, / temtasti laqueum si faceret genitor. / cedite iam veterum laudes omnesque maritae, / tempora nulla dabunt talia quae faciat. / vir tuus ingenti gemitu fletuque rigatus / hos feci versus pauca tamen memorans. ${ }^{35}$

Left tablet: Pontia, who once aspired to starry countenances, lies here: she was offspring of heavenly seed. Every honour, every grace of beauty yielded to you, and you had a mind, too, which, dignifying, shone alongside your appearance. Entrusted to a conjugal bed as young girl, she did not last till the end of the tenth year of her marriage, she died, wretched, with single issue. What love! How welcome to her husband the goodliness of her mind! How chaste her character! How grand her very bashfulness! There was nothing foul in you, nor did you have any weakness of character: as you were obedient, you were called your husband's servant.

Right tablet: Eventually Corsica saw you, in tears, when you followed me, aggrieved by fate and hatred. Carrying on to Trier, conveyed by the spin of the wheels, alas! Your husband's comforter, you suffered hardship aplenty. When your hostile father desired to take you away from his son-in-law, you would have attempted to hang yourself, had your father gone through with it. Yield already, praises of previous generations and all wives, time will create no one to achieve the like. I, your husband, drenched in immense wailing and crying, have made these verses, and yet recorded only little. ${ }^{36}$

The first ten verses make use of generic phrases and stereotypes to characterise Pontia as an embodiment of ideal behaviour. She is identified as a wife and a mother of a single child. The phrase infelix unica prole perit has prompted Hieromymus Geist to conclude that Pontia died during childbirth ("O Qual, starb an dem einzigen Kind"), but although it cannot be ruled out as a possibility, it does not have to be the only scenario, as will become clear. ${ }^{37}$ In addition, the list of traditional values she incorporated is long: she is praised because of her beauty, sound mind (mentioned

34 For the reconstructions, see Garrucci 1879, 150; the edition in ILCV 1540 (by E. Diehl); Bovini 1950, 182.

35 CIL XI 4631 (=ILCV $4812=$ CLE $1846=$ ICI 6.41).

36 The translation is taken from P. Kruschwitz, at https://thepetrifiedmuse.blog/2015/05/12/what-happened-topontia-or-how-a-husband-buried-his-beloved-wife-and-still-only-managed-to-talk-about-himself/(consulted on 9 December 2019).

37 Geist 1969, 37 no. 38 (note that the German translation omits the first five lines of the epitaph). 
twice), chastity and sense of modesty. In general, she was without vice and of outstanding moral behaviour. The first lines are different from what is usually applied in women's funerary inscriptions, though it is a common philosophical notion to state that the soul is of a divine nature and sent down from heaven..$^{38}$ It probably illustrates Pontia's husband's, who otherwise stays anonymous in the inscription, philosophical interests more than it characterizes Pontia. However, these same lines were part of the reason why in the nineteenth century, the people in the vicinity of the church of San Giovenale, where the inscription was kept until 1900, near the town of Macerino, believed that she was una regina, 'an offspring of heavenly seed' or in other words of royal blood. Giovanni Eroli explained in 1858 that, considering the make-up of the memorial, Pontia clearly belonged to the upper classes, but he saw no reason to believe that she was a royal princess: "Ma è un volgo che parla, e non sa quello che dice, nè addurne ragione alcuna." 39

With regard to the manner of her death, however, he did agree with local tradition. He describes that the locals believed that she died during a traffic accident on the via Flaminia when she was on her way to Trier, which he recognised in the Latin phrase Treviros pergens cursu subvecta rotarum in the second tablet of the panel. However, the only thing the text actually states is that she was on her way to Trier, using a carriage to get there, and that the journey was not a pleasant one. It cannot be excluded that Pontia left Corsica together with her husband, but did not get further than Carsulae, where the inscription was found. With regard to the manner of her death, however, and the fate of her child, we remain clueless. Even a scenario in which she died during childbirth in Carsulae, during a journey from Corsica to Trier, should not be excluded. It could, for instance, explain why Pontia's father intended to separate her from her husband, which, according to the latter, would have led her to commit suicide if he had gone through with it. One could wonder why Pontia's husband found it necessary to include such a dramatic episode in her funerary epitaph. At the very least it shows her devotion to her husband, turning her into an exemplary wife. One could also imagine that, if she had indeed died during labour en route, he felt the need to emphasize that she accompanied him of her own free will. But this, of course, remains speculation.

\section{A peregrinatio out of devotion}

In the second century, Aureliana's travel activities are recorded in an inscription that was found in Auximum and which was set up by her husband Evaristus:

[H]ic sum posita Aurel[iana vixi] ann(os) XXVIII me(nses) II d(ies) XXVII nata in urbe sac[ra] / [pe]regrinata Italiam et [provincias] debitum reddidi Nicomedia et hic transl[ata] / [a] dulcissimo mihi co(n)iu[ge Evarist]o Aug(usti) lib(erto) ut vos viatores legendo sciantis(!) q[ua] / [pi]etate ac castitate cum eo [vivens tal] $i$ merito hoc meruerim in hoc sarcophag[o] (...). ${ }^{40}$

Here I lie, Aureliana. I lived 27 years, 2 months, 27 days, born in sacred Rome. After I travelled in Italy and the provinces, I returned to Nicomedia and I was

\footnotetext{
See Binazzi's commentary in ICI 6.41.

Eroli 1858, 375-378.

CIL IX 5860 (=ILS $8234=I L C V 3302)$.
} 
brought here by my sweetest husband, Evaristus, freedman of Augustus, so that you, travellers, may know by reading this by what devotion and chastity, while living with him, I deserved this tomb (...).

The inscription ends with several formulaic phrases that state that when her dearest husband (dulcissimus coniunx meus) Evaristus dies, no one is allowed to open the sarcophagus, nor to transfer her remains, nor to deteriorate the monument in any way. Those who do will need to pay a fine to the fiscus and to the neighbouring cities of Firmium and Ricina. ${ }^{41}$

Aureliana seems to have been a frequent traveller: she had journeyed on the Italian peninsula and in the provinces, though it is not specified which. She died during her stay in Nicomedia, where she-made explicit by reddidi-had been before, after which Evaristus, an imperial freedman, had brought her remains back to Italy to be buried in Auximum, presumably their home town. It is not made explicit why the pair undertook the long journey from Auximum to Nicomedia, a distance of about $2000 \mathrm{~km}$, but one could imagine that Evaristus' obligations as an imperial freedman forced him to go abroad. Aureliana is characterised as devoted to her husband, exemplified by the traditional virtues of pietas and castitas.

It is remarkable that the main part of her characterisation is dedicated to her travel activities, and not to, as would be expected, a list of her womanly virtues or occupations. Moreover, Evaristus opted for the verb peregrinare, a rare occurrence in inscriptions. As a way to denote mobility peregrinare only occurs nine times in the epigraphic sources, twice to describe a woman (Aureliana and Faenia Filumena, discussed below) and six times for men travellers, in a period covering the first to sixth centuries. ${ }^{42}$ In its earliest meaning, peregrinus was used in legal contexts to denote someone who was not a civis Romanus, someone who had left his home region, had settled amongst Roman citizens and for whom different legal rules applied. Ancient writers used peregrinare to indicate living abroad or more generally to travel, though verbs such as peragere or migrare were usually preferred more. In early Christian thought, it continued to have this general meaning, but it was also used to indicate that Christians were different from non-Christians, strangers as it were, thus echoing the early legal connotation of peregrinare. ${ }^{43}$ Evaristus' choice for peregrinare was perhaps nothing more than a general reference to being mobile, but considering the emphasis on Aureliana's travel activities it is not unthinkable that he intended to evoke her (or their) feeling of deplacement.

The only other inscription that uses peregrinare to describe a woman's journey dates to the third or fourth century and informs us about the death of Faenia Filumena:

\footnotetext{
D(is) M(anibus) / Faeniae Filumen(ae) / quae pietate co(n)iu/gi in provincia(m) pe/regrinata es(t) / Aurelius Sperchi/us uxori cariss/(i)mae et inco $<m=n>p a /$ rabili $\{s\} .{ }^{44}$
}

41 On the problems of interpretation with regard to these final lines, see Laubry 2007, 184-185.

42 Based on a search using the Epigraphik-Datenbank Clauss-Slaby in combination with the Europeana Eagle database. References for the men travellers are: CIL III 11697, CIL V 1818, CIL VI 17690, CIL VIII 5749, CIL IX 5860, ILCV 4707, InscrAqu 3.3364. Peregrinus or Peregrina was a popular name, either as a single nomen or as part of the tria nomina, with 34 examples of men and 51 examples of women.

43 On the meaning of peregrinare in Latin, see Claussen 1991, 33-75.

$44 \quad$ CIL VI 17690. 
To the spirits of the dead of Faenia Filumena, who out of piety for her husband has travelled in the province. Aurelius Sperchus (has set this up) for a most deserving and incomparable wife.

Faenia Filumena's husband made use of the stereotypical imagery to represent his deceased wife: her role as uxor is emphasised and though the list of traditional values is not long - a decision made out of financial rather than ideological motives perhaps- the word incomparabilis functions as a substitute for all virtues that are not mentioned explicitly. The exceptional phrase in provinciam peregrinata est refers to her travel activities. Aurelius Sperchus' choice to mention his wife's willingness to travel in the province, though it remains unclear whether it is meant to refer to a specific location or as a generic term to refer to anywhere outside the Italian peninsula, seems to have been a strategic one. This idea is strengthened by Faenia Filumena's travel motivation that is provided: she undertook her journey(s) out of devotion (pietas) for her husband.

In all the examples above, the women travellers are far and foremost commemorated as uxores, with the obvious exception of Iulia Secunda. The husbands presenting their deceased wives frame their spouses' travel activities as an endeavour they undertook within the context of their social roles. As stated above, women also appropriated traditional values embodied by the socio-cultural construct of matrona when representing themselves, thus sustaining and adding to society's ideological status quo. As, for instance, did Martina in the fourth century CE in her husband's funerary memorial:

- - - - - / qui vixi[t] an[nos] / plus minus XL / Martina cara coniux / quae venit de Gallia / per mansiones L ut / commemoraret memoriam du[lcis/si]mi mariti sui / bene qu(i)escas dulcissime / marite. ${ }^{45}$

[(To $). .$.$] who lived for about 40$ years. Martina, his loving wife who travelled from Gaul for 50 days to commemorate the memory of her dearest husband (has set this up). You will rest well, dearest husband.

This inscription was found in the Veneto region in northern Italy and contains a dedication to a deceased man, whose name was mentioned in the missing upper part of the inscription, on behalf of his wife Martina. She states that she travelled from Gaul to -one presumes- Acelum, the finding spot of the monument, to bury her husband. A trip that lasted as long as the distance covered by 50 mansiones, a reference to sleeping accommodation or stopovers, in most cases about a daytrip apart from one another, which would mean that she travelled a distance of about $1250-1500 \mathrm{~km}$. Admittedly, it is difficult to assess how much of the inscription is missing and, therefore, how detailed Martina's husband is represented in the first part of the epitaph. In the remaining lines of the inscription, however, she and not him is central to the narrative: she presents herself as a loyal and loving (cara) wife, evoked by emphasizing her long journey as well as her love for her husband, who is twice called dulcissimus in only three lines. In this sense, her self-representation aligns with the representations of the 'pious' women travellers examined earlier.

CIL V 2108. 
Yet, the emphasis on travelling as an aspect of dutiful behaviour does not only occur between husbands and wives. In the fourth century CE, Maccusa Muceris and her sister Victoria (who also went by the name of Valeriosa) undertook the long journey from Gaul to Macedonia, to visit their uncle in Edessa:

Bonae memoriae Maccusae / Muceris n(orum) XXII et Victoriae / sive Valeriosae n(orum) XIIII quae / ob desiderium avunculi eorum / Fl(avi) Gemelli v(iri) p(erfectissimi) comitis ab ultima / Gallia per diversa loca provin/ciarum ad provinciam Macedo/niam venerunt ibidemq(ue) post am/plexum eius et completa cupiditate/amoris in civitat $<e=i><E=I>d<e=i>$ ssensifatimunus / compleverunt quibus memoratus / vir laudabilis ut cognoscere/tur iussit eis memoriam fieri. ${ }^{46}$

To the happy memory of Maccusa Muceris, age 22, and Victoria or Valeriosa, age 14, who according to the wish of their uncle Flavius Gemellus, a most outstanding man and comes, came from the farthest part of Gaul through various places in the provinces to the province of Macedonia, and, after they had embraced him there and fulfilled love's desire, fulfilled the task of fate in the city of Edessa. In order that this may be known the aforesaid and praiseworthy man ordered this memorial to be set up for them.

After their arrival, both women died, which resulted in a monument set up by their uncle Flavius Gemellus, a vir perfectissimus who is also known through another inscription. ${ }^{47}$ Here, not the deceased women are central to the narrative but the commemorator: his status is emphasised as well as his 'praiseworthy' character. In a way, it resembles Martina's narrative strategy in the remaining lines of her memorial to her husband. Maccusa Muceris and Victoria/Valeriosa's journey is presented as a token for their devotion to him and, one could argue, as an illustration of his power of persuasion.

\section{Conclusion}

With the fate of Cornelia Tyche and her daughter Julia Secunda in mind, it is safe to say that it is more likely to find a woman's journey commemorated when it ended in tragedy. Previous research has shown that in cases of unexpected and tragic deaths, the dedicators of funerary monuments often deviate from the general epigraphic rules and formulas, to elaborate upon the personal drama they and the deceased had experienced. In 1995, in a study on the appearance of violent deaths in funerary inscriptions, Adda Gunnella concluded that the wealthy middle-class followed this practice more than the members of the upper-class. ${ }^{48}$ Those travels in which nothing extraordinary happened usually escape our attention, as they do not figure in much detail (if at all) in funerary inscriptions. Perhaps these 'ordinary' journeys are more easily traced through votive inscriptions. But even in those cases, however, as the example of Vibia Pacata illustrated, a woman's mobility

\footnotetext{
CIL III $14406(=I L S 8454=A E$ 1902, 155).

PLRE I no. 388.

Gunnella 1995, 9-22.
} 
can be subtly woven into the fabric of the inscription's vocabulary, thus easily escaping our attention.

Funerary inscriptions only shed light on small aspects of the practice of women's travels in the Roman Empire. They give us an insight in the distances that were covered (from Gaul to northern Italy or Macedonia, from the Italian peninsula to the coast of Spain, to Nicomedia, to Moesia, to Corsica or to Trier), thus clearing up at least one prejudice that seems to persist in modern scholarship: women did engage in (long-distance) travel indeed. Some of these inscriptions elaborate on the means of transportation or the obstacles along the road. The inscriptions are less clear about the companions with whom these women travelled: some of them travelled in group, others make no mention of companions. Funerary inscriptions make it clear that travel was not only the prerogative of imperial, senatorial or equestrian women. Wives of freedmen or merchants, female slaves and others are equally attested as travellers.

Because of the small sample of inscriptions discussed in this contribution, it is impossible to see differences in narrative strategies over time. Obviously, there are shifts in general commemoration practices (e.g. the introduction of sarcophagi) and in the preference for particular words (e.g. verecundia instead of modestia in Late Antiquity). However, a more detailed and exhaustive analysis is needed to examine whether there is, for instance, an increase in the commemoration of women's travel activities in funerary monuments when travel becomes a more accepted part of daily life (or the opposite). Moreover, one needs to wonder whether a more complete sample would allow to distinguish between local commemorative practices. Besides a systematic examination of the regionally categorized collections in Corpus Inscriptionum Latinarum or an in-depth study of the Carmina Latina Epigraphica, adding Greek funerary inscriptions would be another way to achieve this end. ${ }^{49}$

As stated above, the dominant narrative strategy in funerary inscriptions, whether it commemorated the death of a woman or it was set up by a woman, was to characterise a woman as the embodiment of ideal behaviour by way of listing a canonical set of virtues or to emphasise her social role in the household as wife, mother, daughter or sister. Graeco-Roman society assigned to women a place in the private sphere, in the domain of the household. Keeping that in mind, travel is by default a disruptive activity as it took women out of the household and into the public world. When a commemorator made the deliberate choice to include a reference to a woman's journey -in most of the examples we witnessed in this contribution over quite an impressive distance- he or she must have been well aware of the fact that such an inclusion deviated from the canonical description of a woman as an ideal matrona. I would like to argue that this awareness and the desire to conform to the dominant ideological discourses of their time led to the embedment of these small travel accounts in a broader discourse of ideal female conduct. The commemorated women did not travel for the mere sake of seeing other places, but they did so out of devotion for their husbands. Their love for those who are left behind is mentioned emphatically. Moreover, besides as travellers, they are always also characterised as stereotypical matronae (or proto-matronae in the case of the deceased young

49 For the Greek inscriptions Tacoma - Tybout 2016 forms an excellent starting point; Arena - Bitto 2006 have identified 20 inscriptions in the CLE that focus on women who died in 'foreign lands', thus also offering an ideal base for future research. 
girls). Telling the story of their journeys turns these women into individuals; yet, emphasising their traditional behaviour makes them one amongst many other women at the same time.

\section{References}

Arena, M. - Bitto, I. (eds.), (2006): "Il motivo della morte in terra straniera nei CLE bücheleriani”, [in] A. Akerraz (ed.), L'Africa romana. Mobilità delle persone e dei popoli, dinamiche migratorie, emigrazioni ed immigrazioni nelle province occidentali dell'Impero romano. Atti del XVI convegno di studio, Rabat, 15-19 dicembre 2004, Roma, 1021-1042.

Binazzi, G. (cur.), (1989): Inscriptiones Christianae Italiae 6. Regio VI. Vmbria, Bari (=ICI 6).

Bovini, G. (1950): Monumenti figurati paleocristiani conservati a Firenze (=Monumenti di Antichità Cristiana 6), Città del Vaticano.

Bücheler, F. - Lommatzsch, E. (1930): Carmina Latina Epigraphica, Leipzig (=CLE).

Cantarella, E. (2001): Passato prossimo. Donne romane da Tacita a Sulpicia, Milano.

Casamassima, E. - Rubinstein, R. (eds.), (1993): Antiquarian Drawings from Dosio's Roman Workshop (=Regione Toscana. Inventari e cataloghi toscani 45), Milano.

Cenerini, F. (2009): La donna romana, Bologna.

Claussen, M. A. (1991): "Peregrinatio and Peregrini in Augustine's City of God", Traditio 46, 33-75 (https://doi.org/10.1017/S0362152900004190).

Connell, R. W. (1987): Gender and Power: Society, the Person and Sexual Politics, Cambridge.

De Ligt, L. - Tacoma, L. E. (eds.), (2016): Migration and Mobility in the Early Roman Empire (=Studies in Global Migration History 23/7), Leiden (https://doi. org/10.1163/9789004307377).

Dessau, H. (1892-1916): Inscriptiones Latinae Selectae, Berlin (=ILS).

Diehl, E. (1925-1967): Inscriptiones Latinae Christianae Veteres, Berlin (=ILCV).

Eroli, G. (1859): Miscellanea Storica narnese compilate per Giovanni march. Eroli socio dell'Istituto, vol. 1, Genova.

Fenet, A. (2011): "Voyages en mer dans le monde grec et romain", [in] Thesaurus cultus et rituum antiquorum, vol. 6: Stages and circumstances of life: work, hunting, travel, Los Angeles-Basel, 405-414, with plates 118-120.

Fischler, S. (1994): "Social stereotypes and historical analysis. The case of the imperial women at Rome", [in] L. J. Archer - S. Fischler - M. Wyke (eds.), Women in Ancient Societies. An Illusion of the Night, New York, 115-133 (https://doi.org/10.1007/978-1349-23336-6_7).

Foubert, L.

(2013): "Female travellers in Roman Britain: Vibia Pacata and Julia Lucilla", [in] E. A. Hemelrijk - G. Woolf (eds.), Women and the Roman City in the West (=Mnemosyne, Suppl. 360), Leiden, 391-403 (https://doi.org/10.1163/9789004255951_021).

(2016a): "The lure of an exotic destination: the politics of women's travels in the Early Roman Empire", Hermes 144, 462-487.

(2016b): "Migrant women in P.Oxy and the port cities of Roman Egypt: tracing women's travel behaviour in papyrological sources", [in] de Ligt - Tacoma (eds.), 2016, 285-304 (https://doi.org/10.1163/9789004307377_014). 
Frass, M. (2006): "Reiselustige Frauen im römischen Ägypten", [in] R. Rollinger - B. Truschnegg (eds.), Altertum und Mittelmeerraum: die antike Welt diesseits und jenseits der Levante. Festschrift für Peter W. Haider zum 60. Geburtstag (=Oriens et Occidens 12), Stuttgart, 485-497.

Garrucci, R. (1879): Storia dell' arte Cristiana nei primi olto secoli della chiesa, vol. 5, Prato.

Geist, H. (1969): Römische Grabinschriften, München.

Guédon, S. (2010): Le voyage dans l'Afrique romaine (=Ausonius Éditions. Scripta Antiqua 25), Bordeaux.

Gunnella, A. (1995): "Morti improvvise e violente nelle iscrizioni latine", [in] F. Hinard M.-F. Lambert (eds.), La mort au quotidien dans le monde romain. Actes du Colloque organise par l'université de Paris IV (Paris-Sorbonne, 7-9 Octobre 1993), Paris, 9-22.

Hamdoune, C. (éd.), (2011): Vie, Mort et poésie dans l'Afrique romaine d'après un choix de Carmina Latina Epigraphica (=Collection Latomus 330), Brussels (=CLEAfrique).

Handley, M. (2011): Dying on Foreign Shores. Travel and Mobility in the Late-Antique West (=Journal of Roman Archaeology Supplementary Series 86), Portsmouth (Rhode Island).

Hemelrijk, E. A. (2017): Hidden Lives, Public Personae: Women and Civic Life in the Roman West, London-New York (https://doi.org/10.1093/acprof:oso/9780190251888.001.0001).

Horden, P. - Purcell, N. (2000): The Corrupting Sea. A Study of Mediterranean History, Cambridge, 2000.

Huskinson, J. (2011): "Bad deaths, better memories", [in] V. M. Hope - J. Huskinson (eds.), Memory and Mourning. Studies on Roman Death, Oxford, 113-125.

Iglesias Gil, J. M. - Ruiz Gutiérrez, A. (eds.), (2011): Viajes y cambios de residencia en el mundo romano, Santarder.

Isayev, E. (2017): Migration, Mobility and Place in Ancient Italy, Cambridge (https://doi. org/10.1017/9781316440612).

Laubry, N. (2007): “Le transfert des corps dans l'Empire romain. Problèmes d'épigraphie, de religion et de droit romain", Mélanges de l'École française de Rome. Antiquité 119, 149-188 (https://doi.org/10.3406/mefr.2007.10331).

Lo Cascio, E. - Tacoma, L. E. (eds.), (2016): The Impact of Mobility and Migration in the Roman Empire. Proceedings of the Twelfth Workshop of the International Network Impact of Empire (Rome, June 17-19, 2015), (=Impact of Empire 22), Leiden (https://doi. org/10.1163/9789004334809).

Merkelbach, R. - Stauber, J. (1998-2004): Steinepigramme aus dem griechischen Osten, Stuttgart-Leipzig, 5 vols. (=SGO).

Merlin, A. (1944): Inscriptions Latines de la Tunisie, Paris (=ILTun).

Messerschmidt, J. W. (2011): "The struggle for heterofeminine recognition: bullying, embodiment, and reactive sexual offending by adolescent girls", Feminist Criminology 6, 203-233 (https://doi.org/10.1177/1557085111408062).

Mirón, D. (2008): "Helvia y los viajes. A propósito de Séneca, Ad Helviam matrem de consolatione", Les Études Classiques 76, 233-254.

Moatti, C. - Kaiser, W. (eds.), (2007): Gens de passage en Méditerranée, de l'Antiquité à l'époque moderne, Paris.

de Montfaucon, B. (1722): L’Antiquité expliquée et représentée, vol. 5.1, Paris.

Navarro Caballero, M. (2017): Perfectissima femina. Femmes de l'élite dans l'Hispanie romaine (=Ausonius Éditions. Scripta Antiqua 101), Bordeaux.

Noy, D. (2000): Foreigners at Rome. Citizens and Strangers, London. 
Parker, G. (2008): "The gender of travel: Cynthia and others", [in] R. Ferri - J. M. Seo - K. Volk (eds.), Callida Musa: Papers on Latin Literature in Honor of R. Elaine Fantham (=Materiali e discussioni per l'analisi dei testi classici 61), Pisa-Roma, 229-243.

Parkin, T. G. - Pomeroy, A. J. (2007): Roman Social History. A Sourcebook, London-New York (https://doi.org/10.4324/9780203960844).

Pavón, P. (ed.), (2018): Marginación y mujer en el Imperio romano, Roma.

Riess, W. (2012): "Rari exempli femina: female virtues on Roman funerary inscriptions", [in] S. L. James - S. Dillon (eds.), A Companion to Women in the Ancient World, Oxford, 491-501 (https://doi.org/10.1002/9781444355024.ch36).

Tacoma, L. A. (2016): Moving Romans. Migration to Rome in the Principate, Oxford (https:// doi.org/10.1093/acprof:oso/9780198768050.001.0001).

Tacoma, L. A. - Tybout, R. A. (2019): "Inscribing Near Eastern mobility in the Hellenistic and Roman periods", [in] J. Yoo - A. Zerbini - C. Barron (eds.), Migration and Migrant Identities in the Near East from Antiquity to the Middle Ages, London-New York, 43-69 (https://doi.org/10.4324/9781351254762-4).

Tomlin, R. S. O. - Wright, R. P. - Hassall, M. W. C. (2009): The Roman Inscriptions of Britain. Inscriptions on stone found or notified between 1 january 1955 and 31 december 2006, Oxford (=RIB 3).

Tybout, R. A. (2016): "Dead men walking: the repatriation of mortal remains", [in] De Ligt Tacoma (eds.), 2016, 390-437 (https://doi.org/10.1163/9789004307377_017).

Van Bremen, R. (1996): The Limits of Participation: Women and Civic Life in the Greek East in the Hellenistic and Roman Periods (=Dutch monographs on ancient history and archaeology 15), Amsterdam.

Williams, P. L. (1940-1941): "Two Roman reliefs in Renaissance disguise", Journal of the Warburg and Courtauld Institutes 4, 47-66 (https://doi.org/10.2307/750122).

Wrede, H. (1981): Consecratio in formam deorum: vergöttliche Privatpersonen in der römischen Kaiserzeit, Mainz.

Wypustek, A. (2013): Images of Eternal Beauty in Funerary Verse Inscriptions of the Hellenistic and Greco-Roman Periods (=Mnemosyne, Suppl. 352), Leiden (https://doi. org/10.1163/9789004233201).

Yoo, J. - Zerbini, A. - Barron, C. (eds.), (2019): Migration and Migrant Identities in the Near East from Antiquity to the Middle Ages, London-New York. 